\title{
Letter, E-mail, SMS
}

Giuriato, Davide

DOI: https://doi.org/10.1515/9783110279818-078

Posted at the Zurich Open Repository and Archive, University of Zurich ZORA URL: https://doi.org/10.5167/uzh-168661

Book Section

Published Version

Originally published at:

Giuriato, Davide (2019). Letter, E-mail, SMS. In: Wagner-Egelhaaf, Martina. Handbook of autobiography / autofiction, Vol. 1: Theory and concepts of autobiography / autofiction. Berlin, Boston: De Gruyter, 617-625.

DOI: https://doi.org/10.1515/9783110279818-078 


\title{
3.22 Letter, E-mail, SMS
}

\author{
Davide Giuriato
}

\section{Definition}

A letter is a message in writing that is highlighted on a surface with a writing instrument and corresponding liquid, prepared for dispatch, and forwarded to someone not present over a spatial distance before being received by the addressee after a time delay. Regardless whether a reply and thus a dialogical exchange of letters ensues, the letter represents an event geared towards communication that in terms of both its production as well as reception is tied to specific institutional, material, and media arrangements and is singular in character.

An E-mail (abbreviation of 'electronic mail') is a text message in letter form that is typed on a keyboard and sent electronically via a mail server across a computer network. Regardless of the geographical distance, normally an E-mail can be received by the addressee within a few seconds of its forwarding.

A SMS (abbreviation of 'short message service') is a short text message limited to 160 characters and immediately transmitted mostly by cell phone (but also the internet) via a short message service center (SMSC) to the device of the receiver. For longer messages ('Long SMS') the text is divided into several parts which are sent separately.

\section{Explication}

Up until the discovery of the electrical telegraph in the nineteenth century the letter was the predominant means for communicating and maintaining relationships over distances. Since Antiquity the practical rules of epistolary communication are based on an 'autobiographical pact' guaranteeing the identity of the author, the authenticity of the writing and its subject matter, thus furnishing referential reliability (Lejeune 1975). Considering that the eighteenth and nineteenth centuries are the pinnacle of letter culture, the classical autobiography, the diary and the letter are the central means in the formation of culture of inwardness that genuinely constitutes itself through the medium of writing (Schulze 1996; Koschorke 1999). The letter is thus an object of cultural value that since the twentieth, and more so since the twenty-first century, seems to be vanishing as a result of competition with other communication technologies, specifically E-mail and SMS. In comparison with the accelerated possibilities afforded by new media, this traditional means of forwarding messages is indeed being devalued as 'snail mail'. According to Reinhard Nickisch's analysis 
however, communication via E-mail and SMS is nothing but the continuation of correspondence through the letter by other means (Nickisch 2003, 72). Hence, the history of the letter needs to be surveyed not with a view to the supposed end of the culture of correspondence based on exchanging letters but rather in accordance with the historically changing communication technologies, and this means: in light of the specific media conditions and possibilities.

\section{Systematic Aspects of the Letter}

Since Antiquity letters have been understood on the one hand as historical-biographical documents (private letter, official letter, business letter, open letter, etc.), and as an example of a philosophical or literary genre on the other (philosophical letters, travel letters, epistolary novel, etc.). In both cases epistolary communication gains its characteristic tension through how the real written message addressing someone absent is to replace or simulate the verbal conversation between two present persons, and that the dialogical structure of the utterance made in a letter is conceived from a constitutive monological situation, from an act of solitary writing or reading. This liminal position, determining definitions of the letter since ancient times, has led to a variety of views in research. Firstly, the affinity to verbal communication is anchored structurally in such a way that the written aspect of epistolary production is devalued methodologically as an incidental formality and pressed into the background in favor of perspectives exploring social and cultural history (e.g. Steinhausen 1889/1891; Nickisch 1991). In contrast, starting from the concrete pragmatic context, meaning that any composing of a letter is coupled to the respective historically variable conventions and specific technological conditions, theoretical approaches to the letter assign a fundamental role to precisely these supposed accidental aspects of writtenness and the inherent logic of a particular media (e.g. Joost 1993; Siegert 1993). Far from functioning solely according to the laws of verbal conversation, communicating a message by letter is more than merely producing and reading linguistic signs and the information conveyed - instead, the function played by the medium is also determined by an array of material criteria: simply the choice of paper (e.g. format, color, quality), the writing instrument (stylus, quill, pencil, typewriter, etc.), or the liquid used (wax, ink, etc.), the arrangement of the writing surface (e.g. the layout of the salutation, the text body, and the ending), the different ways of rendering the written content (e.g. handwritten, typewritten), the manner of its sending (folded, sealed, placement in an envelope, the addressing, franking, etc.), and the means of transportation (messengers, couriers, mail coach, rail, ship, airplane, etc.) - in short: the unique character of a letter and its attendant circumstances possess semiotic and aesthetic qualities and thus represent a more or less codified message (Bohnenkamp and Wiethölter 2008, IX-X). In the light of these preliminary considerations, it is worth keeping in mind that existing definitions of the letter fail to 
take into account the material and phenomenal dimension of the written document (e.g. Müller 1994).

\section{On the History of the Letter}

For centuries the epistolary form of communication is framed by guidelines as to its composition. From Antiquity until well into the Early Modern period both the theory and practice of letter writing are programmatically influenced by rhetoric. Mistakenly attributed to Demetrius of Phalerum from the fourth century before the Common Era,

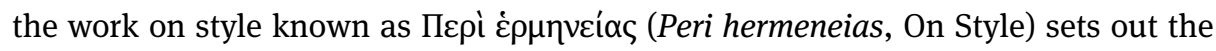
postulates of correspondence established as topoi for the first time: related to oral expression, the letter is to be written in a plain and clear style, revealing the soul of its writer. Although it is recognized that the epistolary exchange is one of the two sides of a dialogue, Pseudo-Demetrius underlines that, unlike the dialogue, the written form demands greater care and is sent as it were as a $\delta \tilde{\omega}$ pov (doron, gift) (Demetrius 1969, 173-177). Accordingly, for a long time writing a letter remained oriented on the standards of oratory formulated in Antiquity and its arrangement ('dispositio') [into five parts: formulaic greeting ('salutatio'), securing the goodwill of the addressee ('captatio benevolentiae'), exposition of the occasion for writing the letter ('narratio'), justifying a request or the cause ('petitio'), and the ending ('conclusio').

Based on these conventions, medieval epistolography removed the letter from its embedment in the rhetorical context and elevated it to the status of an independent subject to be taught (Camargo 1992). Against the backdrop of social changes (primarily in the fields of trade, law, and administration), the 'ars dictaminis' (designating the discipline) or the 'ars dictandi' (the handbooks) extended the scope of letter writing to include specific criteria for written forms of presentation. Greater attention is paid to the social position of the correspondents in the model of a chancery letter for example, leading to the formulation of formulaic phrases and forms of address befitting social status. To write a letter in this context means to produce texts according to prescribed models (Ludwig 2005, 209).

That epistolary production modeled on the criteria of rhetoric continued well into the Early Modern period however is witnessed by the treatise De conscribendis epistolis ['On the Writing of Letters'] (1522) by the humanist Erasmus from Rotterdam. Although this manual presents examples for different kinds of letters, drawing on the classical stylistic precepts for their writing, a burgeoning awareness of freedom in the composition is evident in the area of the familial private letter (Müller 1994, 71).

The fact that subsequent letter writing remains bound to the stylistic precepts of simplicity and clarity makes the detachment from the standard set of rules of rhetoric and the concomitant turn towards the ideal of naturalness, increasingly prominent and discernible throughout the seventeenth (England and France) and eighteenth centuries (Germany), seem like a license for 'free' expression. Preeminently through 
Christian Fürchtegott Gellert's Gedanken von einem guten deutschen Briefe ['Thoughts on a Good German Letter'] (1742) and Briefe, nebst einer Praktischen Abhandlung von dem guten Geschmacke in Briefen ['Letters, together with a practical treatise on good taste in letters'] (1751) a letter culture anchored in civilian society is codified in which writing for the purpose of carrying out a spontaneous and confessional soulful dialogue between two confidants is firmly defined as a substitute for direct speech and becomes the focus of a literature and culture of inwardness. That at the same time this practice never loses sight of the parameters of the written form is indicated by the Allgemeine deutsche Briefsteller ['Guide to German Letter-writing'] from 1793: “Auch auf das Äußere des Briefes verwende man die nöthige Sorgfalt, denn selbst bei Briefen machen Kleider Leute" ['Necessary care also needs to be given to the exterior of the letter, for even with letters clothes make the man'] (Moritz 1832, 94).

The history of the letter shows that the material aspects of correspondence practice assume a fundamental role and that letter writers make every effort to find the suitable 'clothing'. It is known for instance that Georg Christoph Lichtenberg repeatedly drew attention to the non-language requirements of writing a letter - a studiously calculated handling of the entire undertaking is discernible, extending from the paper and quill, the ink, the blotting sand, and the folding through to the sealing, addressing, and forwarding (Joost 1993, 63-79). In a letter from 16 November 1776 to Christiane Dietrich he gives the reason for choosing a pink-colored large quarto sheet with gild edging: "Eine nicht ganz ungewöhnliche Bitte thue ich an Sie auf einem ganzt ungewöhnlichen Papier. [...] Nehmen Sie diesen kleinen muthwilligen Gedancken als eine kleine Vergoldung der Bitte an. Das Papier ist schon vergoldet” ['I put forward to you a not quite uncommon request on quite uncommon paper. [...] Take this small mischievous thought as a small gilding of the request. The paper is already gilded'] (Joost 1993, 126). This sensual quality of the letter can come to the fore in fictive letters as well. In the revised edition of Goethe's Die Leiden des jungen Werthers (1774/1787) [The Sorrows of Young Werther (1779)] for example the protagonist writes to Lotte on July 26: "Keinen Sand mehr auf die Zettelchen die Sie mir schreiben. Heute führte ich es schnell nach der Lippe und die Zähne knisterten mir” [“please don’t sprinkle sand on the little notes you write. I pressed today's quickly to my lips and my teeth grated”] (Goethe 1994, 83 [2012, 35]). The invention of blotting paper some decades later would solve this and similar problems for ardent letter readers and replace the sand-blotting pot used by Goethe himself.

Since the mechanization of written production at the end of the nineteenth and the general acceptance of the typewriter in the first third of the twentieth century, the choice of the instrument employed when writing becomes contentious, particularly in relation to the question of the intimacy of conducting a dialogue by letter and accordingly one's own handwriting as an essential characteristic of the private letter. Hermann Hesse for example greatly appreciated - although handwriting supposedly lends the message greater individuality - the 'anonymous' face of typewriting and exploited it as an opportunity to experiment with letters typed in a variety of colors 
(Bohnenkamp and Wiethölter 2008, 36). In contrast, Walter Benjamin, Robert Walser, and Rainer Maria Rilke, each of whom left behind an important corpus of letters, are amongst those letter writers who at the beginning of the twentieth century deliberately refrained from using a typewriter, preferring the freedom of arrangement afforded by handwriting. On the other hand, Else Lasker-Schüler feels the need to justify using a typewriter so as to ensure that the addressee does not doubt the intimacy of what she writes: "Ich schreibe mit der Maschine meiner Hand wegen, die mir weh tut. Verzeihen Sie bitte" ['I'm typing because my hand is aching. Please excuse'] (Bohnenkamp and Wiethölter 2008, 15).

Of course, the materiality of writing is of vital importance not only for the aesthetic and semiotic quality of the letter. As an example from the letters of Rainer Maria Rilke shows, precisely the writtenness of epistolary communication provides the scope necessary for transgressing the traditional borders between genres, enabling the letter to become an autobiographical text. Lasting just a month, the intensive correspondence with the Viennese pianist Magda von Hattingberg is characterized by how Rilke does not write his letters on letter paper: "Mein Papier, Briefpapier, ist nun da, gute Freundin, aber ich will großsprechen und sagen: es war immer meine Gewohnheit, Ihnen auf diesem hier zu schreiben, auf dem ich gewöhnlich arbeite, mag es dabei bleiben" ['My paper, the stationery, is here now, good friend, but I want to boast and say: it has always been my custom to write to you on this paper I normally use for working, let it remain that way'] (Rilke 2000, 27). For Rilke, the paper normally used for work is tied to the liberating consequence that what he writes need not heed any criterion, so what he expresses soon indeed becomes an intimate diary. In the letter from 16/20 February 1914, wherein Rilke calls his letters to her "Brief-Titanen” ['letter-titans'] (Rilke 2000, 119), he can thus claim: "Ich schreibe weiter, Du theures Mädchen, dieses unbegreifliche Journal meines Leben-Wollens an Dein Herz" ['I continue writing, addressing to your heart this incomprehensible journal of my desire to live'] (Rilke 2000, 111). Amounting to no less than thirty-one manuscript pages, with this letter Rilke emphasizes a functional equivalence between epistolary communication and autobiographical confession that is rooted in the media conditions of writing (see Giuriato 2010).

\section{Letter - E-mail - SMS}

If the eighteenth and nineteenth centuries are generally regarded as the pinnacle of letter culture, the history of telecommunications media since the emergence of the telegram (1874), the postcard (1847), and the telephone (in Germany from 1877) has concomitantly witnessed - thanks to the competition unleashed - a gradual and repeatedly lamented demise of the letter. Although epistolary exchange in the traditional form seems to have all but disappeared since the end of the twentieth century with the sweeping success of digital transmission of data, it is nonetheless advisable to desist 
from joining the emphatic chorus of cultural criticism. The present transformation ushered in by new media technology has led rather to a pluralization of communication cultures (letter culture, telephone culture, cell phone culture, E-mail culture). The variety of media makes several switching technologies readily available today, and the 'diversity demands decisions, several times a day: one has to consider how one wishes to communicate with someone, what kind of influence the chosen medium has on the message, and which channels the recipient uses in which way' (Stock 2001, 47).

Against the background of this entangled situation, which at times triggers 'uncertain behavior' when dealing with existing and new media, it is not only the question as to the rules of communication which needs to be continually reconsidered (Höflich and Gebhardt 2003, 8). The diversity and heterogeneity of the available communication media also indicates the need to differentiate functionally between their various usages and to take into consideration the metacommunicative significance of the individual medium. Empirical studies suggest that the private letter has lost none of its importance and credibility as a means of emotional exchange, although it has long been surpassed quantitatively by E-mail and SMS in terms of user preference (Leppänen 2001; Höflich and Gebhardt 2003). In contrast, the time interval required by the communication process in the case of E-mail and SMS, a consequence of the respective technology, apparently brings with it 'more immediate contact', which can however be connoted with a lower degree of commitment (Meier 2002, 69). Finally, the elliptical style of SMS communication (leaving out the subject pronoun, absence of sequences for greetings or saying goodbye, abbreviating words and sentences) as distinct from the letter and the E-mail is connected with a functional orality, highlighting the recurrence of situation-deictic elements (Dürscheid 2002).

For letters generally it is thus necessary to consider that for all the freedom they afford in terms of their compositional arrangement, they are always written within the framework of rhetorical and material conventions as well as specific media and historical conditions. With regard to both private as well as official letters it can depending on the circumstances - make a significant difference whether in the digital age one writes an E-mail, an SMS, or a handwritten or typewritten letter, whether one decides to use in vogue retro design products such as handmade paper, ordinary writing paper, or preprinted paper with letterhead, whether one scents the letter or not, whether one folds the letter and has it sealed or simply places it in an envelope, whether one writes in blue, black, red ink or uses a pencil, etc. All the traces visible on the sheet of paper or on the screen, whether specifically stemming from the act of writing or otherwise, can be read by the recipient and, if need be, interpreted. Thus, whenever the letter is drawn on as a historical or (auto-)biographical information source, its staged character, or more generally, the specific contours of its appearance need to be considered closely. Upon adopting such an approach it becomes quickly clear that, ultimately, the letter defies reproduction. A facsimile can be made of a letter, or it can be photographed, scanned, filed, or exhibited in a museum - only the original document can convey a sense of its singularity. The letter is in itself an event, 
an event that can tell entire stories through its material properties and the peculiar features of its respective medium. This not only pertains to all that the writer does in arranging and then sending the document. Once out of their hands and forwarded the letter embarks on a - at times - long journey fraught with danger. Along with the sender and recipient, various agents are involved in the conveyance capable of influencing the fate of the letter, likewise that of an E-mail or SMS - no matter whether the intentions are sympathetic or malicious. Whereas postal staff in democratic societies are obliged to observe the secrecy of letters as a fundamental legal principle, under totalitarian conditions the channels of conveyance represent a gray area in which unknown readers can make trouble as they choose - this secrecy is no less threatened in the case of the E-mail and the SMS given the relatively simply surveillance of the digital medium possible today (Meier 2002, 68).

In the one case as in the other, Franz Kafka's remark in a letter to Milena Jesenská from 1922, claiming that corresponding through letters has something inherently ghostlike about it, seems eerily apt:

Alles Unglück meines Lebens [...] kommt, wenn man will, von Briefen oder von der Möglichkeit des Briefeschreibens her. [...] Die leichte Möglichkeit des Briefeschreibens muss - bloss theoretisch gesehen - eine schreckliche Zerrüttung der Seelen in die Welt gebracht haben. [...] Wie kam man nur auf den Gedanken, dass Menschen durch Briefe miteinander verkehren können! [...] Postalische Küsse kommen nicht an ihren Ort, sondern werden von den Gespenstern auf dem Weg ausgetrunken

[All the misfortune of my life [...] derives, one could say, from letters or from the possibility of writing letters. [...] The easy possibility of letter-writing - seen merely theoretically - must have brought into the world a terrible disintegration of souls. [...] How on earth did anyone get the idea that people can communicate with one another by letter! [...] Written kisses don't reach their destination, rather they are drunk on the way by ghosts] (Kafka 1986, 301, 302 [1999, 182,183]).

Translation: Paul Bowman

\section{Works Cited}

Bohnenkamp, Anne, and Waltraud Wiethölter, eds. Der Brief. Ereignis \& Objekt. Basel/Frankfurt a. M.: Stroemfeld, 2008.

Camargo, Martin. “Ars dictandi, dictaminis.” Historisches Wörterbuch der Rhetorik. Ed. Gert Ueding. Tübingen: Niemeyer, 1992. 1040-1046.

Demetrios. On Style. The Greek Text of Demetrius De Elocutione. Ed. W. Rhys Roberts. Hildesheim: Olms, 1969.

Dürscheid, Christa. “E-mail und SMS - ein Vergleich.” Kommunikationsform E-mail. Ed. Arne Ziegler and Christa Dürscheid. Tübingen: Stauffenburg, 2002. 93-114.

Erasmus von Rotterdam. De conscribendis epistolis/Anleitung zum Briefschreiben (1522). Ed. Kurt Smolak. Darmstadt: Wissenschaftliche Buchgesellschaft, 1995.

Gellert, Christian Fürchtegott. Die epistolographischen Schriften (1742/1751). Stuttgart: Metzler, 1971. 
Giuriato, Davide. "Die unwirthlichen Blätter. Rilke, das Papier, die Post und die Briefe an Benvenuta". Der Brief. Ereignis \& Objekt. Frankfurter Tagung. Eds. Waltraud Wiethölter and Anne Bohnenkamp. Frankfurt a. M.: Stroemfeld, 2010. 134-146.

Goethe, Johann Wolfgang von. Die Leiden des jungen Werthers/Die Wahlverwandtschaften/Kleine Prosa/Epen. Ed. Waltraud Wiethölter. Frankfurt a. M.: Deutscher Klassiker Verlag, 1994 [The Sorrows of Young Werther. Trans. David Constantine. Oxford: Oxford University Press, 2012]. Höflich, Joachim R., and Julian Gebhardt, eds. Vermittlungskulturen im Wandel. Brief, E-mail, SMS. Frankfurt a. M.: Lang, 2003.

Joost, Ulrich. Lichtenberg - der Briefschreiber. Göttingen: Wallstein, 1993.

Kafka, Franz. Briefe an Milena. Ed. Jürgen Born and Michael Müller. Frankfurt a. M.: Fischer, 1986 [Letters to Milena. Trans. James Stern and Tania Stern. London: Vintage Books, 1999].

Koschorke, Albrecht. Körperströme und Schriftverkehr. Mediologie des 18. Jahrhunderts. München: Fink, 1999.

Lejeune, Philippe. Le pacte autobiographique. Paris: Éditions du Seuil, 1975 [On Autobiography. Ed. Paul John Eakin. Trans. Katherine Leary. Minneapolis: University of Minnesota Press, 1989].

Leppänen, Sanne. "The Relationship between Electronic Mail and Paper Mail”. Case Study: Changes in Postal Services - Paper or Bytes? The Consumer Research Project. Ed. Digital Media Institute. Tampere, 2001. 51-80.

Ludwig, Otto. Von der Antike bis zum Buchdruck. Geschichte des Schreibens. Vol. I. Berlin: de Gruyter, 1995.

Meier, Jörg. "Vom Brief zur E-mail”. Kommunikationsform E-mail. Ed. Arne Ziegler and Christa Dürscheid. Tübingen: Stauffenburg, 2002. 57-75.

Moritz, Karl Philipp. Allgemeiner deutscher Briefsteller (1793). Berlin: Rückert, 10th ed. 1832.

Müller, Wolfgang G. "Brief.” Historisches Wörterbuch der Rhetorik. Ed. Gert Ueding. Tübingen: Niemeyer, 1994. 60-76.

Nickisch, Reinhard M. G. Brief. Stuttgart: Metzler, 1991.

Nickisch, Reinhard M. G. "Der Brief - historische Betrachtungen.” Vermittlungskulturen im Wandel. Brief, E-mail, SMS. Ed. Joachim R. Höflich and Julian Gebhardt. Frankfurt a. M.: Lang, 2003. 63-73.

Rilke, Rainer Maria. Briefwechsel mit Magda von Hattingberg. Ed. Ingeborg Schnack and Renate Scherffenberg. Frankfurt a. M.: Insel, 2000.

Schulze, Winfried, ed. Ego-Dokumente. Annäherung an den Menschen in der Geschichte. Berlin: Akademie-Verlag, 1996.

Siegert, Bernhard. Relais. Geschicke der Literatur als Epoche der Post. Berlin: Brinkmann \& Bose, 1993.

Steinhausen, Georg. Geschichte des deutschen Briefes (1889/1891). Dublin/Zürich: Weidmann, 1968.

Stock, Ulrich. “Bitte melde dich!” Die Zeit (19 July 2001): 47-49.

\section{Further Reading}

Baasner, Rainer, ed. Briefkultur im 19. Jahrhundert. Tübingen: Niemeyer, 1999.

Barton, David, ed. Letter writing as a social practice. Amsterdam: John Benjamins, 2000.

Behr, Monique, and Jesko Bender, eds. Emil Behr. Briefzeugenschaft vor, aus, nach Auschwitz. Göttingen: Wallstein, 2012.

Bernard, Andreas. "Im SMS-Stil. Gibt es eine Poetologie der 160 Zeichen? Über den Zusammenhang von Literatur und Medientechnologie." "System ohne General". Schreibszenen im digitalen 
Zeitalter. Ed. Davide Giuriato, Martin Stingelin and Sandro Zanetti. München: Fink, 2008. 189-197.

Dossena, Marina, ed. Letter writing in late modern Europe. Amsterdam: John Benjamins, 2012. Ebrecht, Angelika, ed. Brieftheorie des 18. Jahrhunderts. Stuttgart: Metzler, 1990.

Poster, Carol, and Linda C. Mitchel, eds. Letter-Writing Manuals and Instruction from Antiquity to the Present. Columbia: University of South Carolina Press, 2007.

Stockmar, René. Private Briefe - freie Wissenschaft. Briefe edieren am Beispiel von Friedrich Nietzsches Briefwechsel 1872-1874. Basel/Frankfurt a. M.: Stroemfeld, 2005.

Ziegler, Arne, and Christa Dürscheid, eds. Kommunikationsform E-mail. Tübingen: Stauffenburg, 2002. 